Copyright (C) 2016 by Academic Publishing House Researcher

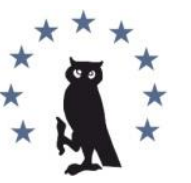

Published in the Russian Federation

European Researcher

Has been issued since 2010.

ISSN 2219-8229

E-ISSN 2224-0136

Vol. 107, Is. 6, pp. 318-323, 2016

DOI: 10.13187/er.2016.107.318

www.erjournal.ru

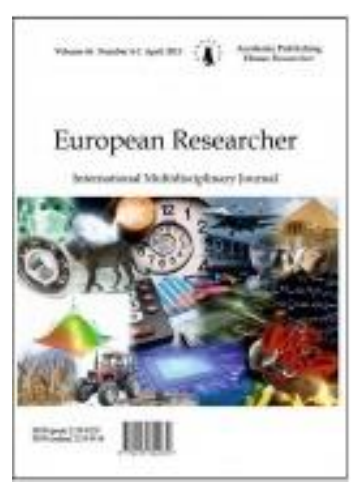

Historical sciences and archaeology

Исторические науки и археология

UDC 930.85

\title{
Collections of the Imperial Orthodox Palestine Society in the State Museum of the History of Religion (Saint-Petersburg, Russia)
}

\author{
${ }^{1}$ Tatiana V. Chumakova \\ ${ }^{2}$ Marianna M. Shakhnovich \\ 3 Ekaterina A. Terukova
}

1-3. St. Petersburg State University, Russian Federation

Mendeleevskaya liniya 5, St.Petersburg 199034

${ }^{1}$ Dr. (Philosophy), Professor

E-mail: t.chumakova@spbu.ru

${ }^{2}$ Dr. (Philosophy), Professor

E-mail:m.shakhnovich@spbu.ru

3 PhD (Philosophy), Associate Professor

E-mail: e.teryukova@spbu.ru

\begin{abstract}
The article is concerned with the main problems of formation's history and exploration of the collections of Imperial Orthodox Palestinian Community (Russia). Its Community in Russia from the moment of its creation (1882) not only engaged in the organization of pilgrimages in Holy Land, but its deals with the organization of systematic archaeological excavations and scientific expeditions in Near East. One of the important but few mentioned aspects of this scientific and cultural activity is the creation of two unique collections - the library's collection and the photo archive. This research is based on the materials collection's of The Imperial Orthodox Palestinian Community, which is saved as a part of the collections of the State Museum of the History of Religion and archive materials that not published yet. The book's and photo's compositions that preserved in the collections of the Imperial Orthodox Palestinian Community reflects not only intellectual inquiries and preferences of Russian scientists but the history of Palestinian science's development in Russia at the end of the XIX - at the beginning of $\mathrm{XX}$ centuries as a whole.
\end{abstract}

Keywords: the Imperial Orthodox Palestinian community, russian culture, the state museum of the history of religion, collections.

\section{Introduction}

The article is devoted to the description of the collections of the Imperial Orthodox Palestine Society and the story of its preservation in the State Museum of the History of Religion. After the 
revolution of 1917 the Orthodox Palestine Society was renamed into the Russian Palestine Society of the Academy of Sciences. The historical name of "The Imperial Orthodox Palestine Society" was returned to it in 1992. The article is based on the archival materials.

\section{Materials and Methods}

The major source for this article is library and other collections of the Imperial Orthodox Palestine Society, which are kept in the State Museum of the History of Religion (Saint-Petersburg, Russia). Source information, concerning these events, was collected on open source resources, namely on books and journal publications. Methods. The article uses historical-situational method, which supposes historic facts study in the context of examined epoch in the aggregate with adjacent events and facts.

\section{Discussion}

The middle of the XIX century was the beginning of the establishment of different organizations involved in the Palestinian studies in the Russian Empire. The Russian Ecclesiastical Mission was founded in 1847 in Jerusalem. It was headed by Archimandrite Porfiry Uspensky. The Mission stopped its activity during the Crimean War and was reopened in 1857 . The main goal of this spiritual mission was to help the pilgrims. A year later, in 1858, the Palestine Committee was established. Its task was to strengthen the presence of the Russian Empire in the Holy Land. Objectives of the committee were somewhat wider; the main objective was to strengthen its Russian cultural and political influence. The committee headed by the Grand Duke Konstantin Nikolaevich started purchasing land in the Middle East and constructing churches, monasteries, schools, etc. The Orthodox Palestine Society (IOPS) was established on May 21, 1882. That date was chosen on purpose, it was the commemoration day of the Byzantine Emperor Constantine and his mother Helena, who were revered by the Orthodox Church equal to the Apostles. Thanks to them two of the most revered Christian Orthodox churches were built in Jerusalem and Bethlehem: Jerusalem Church of Resurrection and the Church of Nativity in Bethlehem. According to the ecclesiastical tradition Empress Helena was also considered to be the first Christian archaeologist. According to the tradition she participated in the first excavations in the Palestinian territories, during which the burial place and the birth-place of Jesus Christ have been found. Christians also believe that Helena was the one to find the cross on which the Christ was crucified.

According to the statute of $1882[1,17]$ the main objectives of IOPS were: to collect information about sacred places on the Holy Land, support the pilgrims; establish schools, hospitals and homes for pilgrims as well as support the local residents and clergy. That determined the three pillars of the Imperial Orthodox Palestine Society: research and publishing activity, organization of pilgrimages and the support of Orthodox believers in the Holy Land. The main goal of the Society was to strengthen the influence of the Russian Empire in the Middle East. The Grand Duke Sergei Alexandrovich was appointed to be its chairman. Thanks to the support of the Government and the assistance provided by the local branches of IOPS in Russia, it was able to carry out all its objectives. By 1917 it released 28 volumes of the "Messages of the Imperial Orthodox Palestine Society" and 62 volumes of "The Orthodox Palestine Anthology." Imperial Orthodox Palestine Society founded in Saint-Petersburg a library and an archive to preserve different documents on Holy Land, mainly photos. A significant part of these collections since the end of the 1930-es was stored in the State Museum of the History of Religion [2].

A collection of objects related to the Russian orthodox pilgrimage to the Holy Land in the second half of XIX- early XX century was of great interest. The collection included photographs, pilgrim souvenirs, books, and works of Russian artists. A unique collection of photos made in the Middle East in the period from 1860 - 1917 was given to the Museum of the History of Religion by the order of the Presidium of the Academy of Sciences of USSR on January 17, 1939. On June 5, 1939 A. Migunov, the scientific secretary of the Manuscript Department of the Institute of Oriental Studies of the Academy of Sciences, and K. Vorontsov, the head of the department of funds of the Museum of the History of Religion of the USSR Academy of Sciences, compiled the Act of transfer. There was stated that by the decision of the Presidium of the Academy of Sciences the director of the Institute of Oriental Studies of the Academy of Sciences academician Barannikov was ought to transfer to the Museum of the History of Religion together with Abyssinian icons (4 items) and Buddhist icons (648 items), the religious objects (82 items) received from the Palestine Society as 
well as a folder with photos of Christian archaeological sites in Asia Minor (Asia Minor, Nicaea, Nicomedia, Chios). The first Russian Ecclesiastical Mission in Jerusalem and later the founders of the Imperial Orthodox Palestine Society paid special attention to the art of photography and the photos not only as the newest tool of scientific exploration of the historical heritage of the Holy Land but also as a way to record its rapidly changing appearance at the turn of the 19-th - 20-th centuries, the successes of the widening Russian missionary activity, the process of construction of new churches and houses for pilgrims. Photography was also supposed to popularize the places linked with the Gospel story. Archimandrite Antonin (A. Kapustin), head of the Russian Ecclesiastical Mission from 1865 to 1894, was fond of photography. In 1892 there was a large exhibition of the photos of the Holy Land in St. Petersburg and Moscow, and in 1894 and 1900 V. Yushmanov prepared and published catalogs of photographic collections of the Imperial Orthodox Palestine Society, which included more than 4,500 images (dating from 1858-1900) [3].

Today the photo collection of the Imperial Orthodox Palestine Society at the Museum of the History of Religion includes about 7,000 prints, as well as several hundred glass plate negatives. Of greatest interest are photos made by famous Russian photographers such as A. Yanyshev, O. Timon, I. Barschevsky, A. Yakubovich, N. Anichkov and others. Photos made in late the 19-th century in the Middle East by Felix Bonfis are of great interest.

The unique item in the Museum's collection is the relief map of the Palestine, made by George Armstrong in 1903. G.Armstrong was a military engineer and assistant secretary at one of the largest Palestine oriented organizations - Palestine Exploration Fund in London, for many years he participated in the detailed description of the landscape of that territory. After seven years of hard work he was able to produce a map that had no analogues in the beginning of the 20-th century in the technique of high-relief out of papier-mache on a scale of 1 inch - 1 mile. [4, 92]. The Map included Western Palestine from Baalbek in the north to Kadesh Barnea in the south and the territories to the east of the Jordan River. The surface topography of Palestine was made remarkably accurate with all the mountains, hills, plains and valleys. Palestine Exploration Fund enshrined the right to reproduce this map. The Fund also established its mass production for the needs of libraries and Sunday schools. The map was made from tinted plaster in two types of wooden frames, fully or partially painted (without geographical names). That was the first and only map of the Holy Land of that time. It showed the geography with such a high degree of accuracy that secured immediately the interest of many foreign research organizations and institutions. The Imperial Orthodox Palestine Society was not an exception.

The library of the Imperial Orthodox Palestine Society is also now a valuable part of the Museum's collection. It is still impossible to determine its original size. According to S. Kleschuk, it included more than 30 ooo items in 1927 [5, 63]. Researchers A. Krylov and N. Sorokina noted that the "Imperial Orthodox Palestine Society had a collection of rare books and manuscripts, which included 20 thousand names" [6, 25]. The systematic catalog of the Imperial Orthodox Palestine Society's library released in 1907, [7] and amended in 1913 [8], did not give a comprehensive view on its original size, as the library continued to grow after its publication. The Russian periodicals numbered 268 titles and 13,652 volumes, the foreign periodicals informed about 119 titles and 1360 volumes.

The library was located in St. Petersburg until 1917, but in the 1920-es, after the reorganization of the Society, the book collection was split several times and in the 1949-es by the efforts of V. Bonch-Bruevich, the director of the Museum of the History of Religion in Leningrad, became the part of the funds of the Museum's Library, where it is stored now (slightly more than 10000 items). The Orthodox Church started to claim all library collections back in the 1950-es (despite the fact that the library never belonged to the Synodal structures and mostly consisted out of personal books of the founder of the Imperial Orthodox Palestine Society V. Hitrovo). From the correspondence between V. Bonch-Bruevich, the Director and M. Shakhnovich, the Deputy Director of the Museum of the History of Religion we know that the library collection was claimed by the Moscow Patriarchate. Bonch-Bruevich noted that the Patriarchate "wanted to have these books for their library in the Trinity-Sergius Lavra. Of course under our Constitution this applicant should not be supported. I, of course, fully expressed the wish to transfer these books from the library of the Palestinian society to the Museum of the History of Religion. They belong to the Academy of Sciences and are stored in the Library of the Academy of Sciences. I will write a letter to the academician A. Topchiev about this, as well as to the Foreign Department. The USSR 
Academy of Sciences for its part will file a petition in this regard to the Presidium"[9]. BonchBruevich's project was successful. Until 1962 the Museum of the History of Religion was an Institute of the Academy of Science, it was easy to transfer of to the library of the Museum of the History of Religion. Another part of the library was transferred to the Institute of Oriental Studies. In 1982 the Academy of Sciences gave 8626 books with the stamp of Imperial Orthodox Palestine Society (including catalogs and inventory books) to the Moscow Patriarchate, further fate of these books is unknown.

The library of Imperial Orthodox Palestine Society of the is preserved as a special collection of the Museum's library, it has its own codes, its own systematization, inventories and catalogs: alphabetical and systematic. All books and brochures have specific bindings with red spines, bookplates and stickers with the emblem of the Imperial Orthodox Palestinian Society.

The diary of Archimandrite Antonin is one of the jewels of this extremely diverse collection of books. For many years Archimandrite Antonin was the head of the Russian Ecclesiastical Mission in Jerusalem. He also established himself as a collector and researcher, author of numerous scientific articles and books on biblical archeology and history of the Middle East. Archimandrite Antonin's diary has already been the subject of study and there were several publications about it [10, 11]. The copy of the diary stored at the Museum of the History of Religion is unique. After the death of Archimandrite Antonin in 1894 the Procurator of the Holy Synod K. Pobedonostev ordered to bring the handwritten diary to St. Petersburg. The Secretary of IOPS V. Hitrovo ordered to copy it. All volumes of the copy were decorated in the same way, i.e. intertwined, and with name index and gold embossing on the spine: "The Diary of Archimandrite Antonin. 1880 ". In the upper left corner on the front of the binding there was a label indicating the code number of the IOPS library and IOPS bookplate inside. Today some volumes of the copy of the diary are stored in different libraries, but the majority of them are in the Museum of the History of Religion: volumes of 1817-1835, 1836-40, 1841-45, 1846-50, 1851 -55, 1856-6o, 1861-65, 1867, 1874, 1875, 1876, 1877, 1878, 1880, 1882, 1883, $1884,1885,1886,1887,1888,1889,1890,1891,1892,1893-94$. Of particular importance to this collection comes the fact that the original manuscript, which now is stored at the Russian State Historical Archive, does not have the 1883-1886 volume. It was lost. The only possibility to recover its contents is the existing copy at the Museum of the History and Religion.

The reports on the activities of the IOPS regional offices from 1893 to 1916 are stored in the library of the Museum of the History of Religion as well. This material is of great interest from the aspect of the history of IOPS in the pre-revolutionary Russia. IOPS regional offices functioned in 52 dioceses. Their aim was to raise money for the Russian Mission in Palestine. The first one was opened in 1893 in Yakutia. The reports were issued at the expense of the regional offices and reflected not only the dynamics of growth of the number of branches, membership in them and their social composition, but also the diversity of IOPS activities, which included delivering "public lectures", purchasing foggy images and devices for their projection, distribution of free brochures and leaflets with views of Palestine to "increase the material resources of the Society through the acquisition of one-time donations", organizing the annual fundraising. The collection includes reports of the following departments: Yaroslavl department (1894-1915), the Yakut department (1893-1903/1904), Chernigov department (1896-1910), Kharkov department (1905-1915), Tula department (1896), Tver department (1896-1904), Tambov department (1902-19130, Tauride department (1900-1904), Stavropol department (1904-1913), Smolensk department (1897-1907), Simbirsk department (1901-1906), Samara department (1914-1915), Ryazan department (18951907), Pskov department (1897/98 and 1904/1905), Poltava department (1898-1906/1907), Podolsk department (1889/1899-1902/1903), Perm department (1899/1900-1906/1907), Orlovsky department (1899/1900-1915), Orenburg department (1899/1900-1910/1911), Olonetsky department (1901/1902-1910/1911), Odessa department (1895/1896-1915), Novgorod department (1989/1899-1915), Kursk department (1901/02-1916), Kostroma department (1899/1900-1914), Kiev department (1906/1907-1914), Chisinau department (1897-1916), Kaluga department (18941899/1900), Kazan department (1904/1905-1906/07), Yenisei department (1901/19021904/1905), Ekaterinoslav department (1897-1909/1910), Yekaterinburg department (1895/18961910/1911), Don department (1897-1904/1906), Vyatka department (1894-1912/1913), Voronezh department (1898-1911/1912), Volyn department (1894/1895-1907/o8), Volgograd department (1896/1897-1915), Vladimir department (1895/1896-1913), Vitebsk department (1902/1903), 
Blagoveshchensk department (1901/1902-1904/1905), Astrakhan department (1896/18971903/1904) and Archangelsk department (1898/1899-1914).

\section{Conclusion}

IOPS collection at the State Museum of the History of Religion is still waiting for its researchers involved in the study of intellectual history and the history of religion, as well as the complex issues related to the history of church-state relations in Russia.

\section{Acknowledgements}

The publication was prepared with the support of RGNF grant " Library of the Imperial Orthodox Palestine Society " as part of the book collection of scientific library of the State Museum of History of Religion "№ 14-63-01001.

\section{Литература}

1. Шахнович М.M., Чумакова Т.В. Музей истории религии Академии Наук СССР и российское религиоведение (1932-1961). СПб.: Наука, 2014.

2. Юшманов В.Д. Собрание фотографических снимков, принадлежащих Императорскому Православному палестинскому обществу. СПб, типография Майкова, 1900.

3. Notes and news // Palestine Exploration Fund. Quarterly Statement. 1894. Интернет pecypc http://en.wikisource.org/wiki/Page:Palestine_Exploration_Fund_-_Quarterly_ Statement_for_1894.djvu/116 Дата обращения: 15 июня 2016 г.

4. Клещук С.Е. Как разоряли библиотеку: из истории современности// Научные и технические библиотеки. Ежемесячный сборник / ГПНТБ России, 1992. № 8. С. 62-65.

5. Крылов А., Сорокина Н. Императорское Православное Палестинское Общество и отечественное востоковедение. Москва, МГИМО-Университет. 2007.

6. Систематический каталог библиотеки Императорского Палестинского Православного общества. Т. 1-2, СПб., типография В.Ф. Киршбаума, 1907.

7. Систематический каталог библиотеки Императорского Палестинского Православного общества. Дополнение к Т. 1-2. СПб, 1913.

8. Письмо В.Д. Бонч-Бруевича М. И. Шахновичу. Ноябрь 1952. Личный архив проф. М.И. Шахновича.

9. Салмина М.А. Дневник архимандрита Антонина (Капустина)// Труды отдела древнерусской литературы. Т.27. Ленинград, 1972. С. 420-430.

10. Лисовой Н.Н., Бутова Р.Б. Архимандрит Антонин и его дневник // Дневник. Год 1881. М., Индрик. 2011.

\section{References}

1. Shahnovich M.M., Chumakova T.V. Muzey istorii religii Akademii Nauk SSSR i rossiyskoe religiovedenie (1932-1961) [Museum of the History of Religion of Academy of Sciences of the USSR and the Russian Religious Studies (1932-1961)]. SPb.: Nauka, 2014.

2. Yushmanov V.D. Sobranie fotograficheskih snimkov, prinadlezhaschih Imperatorskomu Pravoslavnomu palestinskomu obschestvu [Collection of photographs belonging to the Imperial Orthodox Palestine Society]. SPb, tipografiya Maykova, 1900.

3. Notes and news // Palestine Exploration Fund. Quarterly Statement. 1894. Internet resurs http://en.wikisource.org/wiki/Page:Palestine_Exploration_Fund_-

_Quarterly_Statement_for_1894.djvu/116 Data obrascheniya: 15 iyunya $2016 \mathrm{~g}$.

4. Kleschuk S.E. Kak razoryali biblioteku: iz istorii sovremennosti// Nauchnyie i tehnicheskie biblioteki. Ezhemesyachnyiy sbornik [How devastated the library: the history of modernity] / GPNTB Rossii, 1992. № 8. S. 62-65.

5. Kryilov A., Sorokina N. Imperatorskoe Pravoslavnoe Palestinskoe Obschestvo I otechestvennoe vostokovedenie [Imperial Orthodox Palestine Society and native Orientalism]. Moskva, MGIMO-Universitet. 2007.

6. Sistematicheskiy katalog biblioteki Imperatorskogo Palestinskogo Pravoslavnogo obschestva [Systematic catalog of the library of the Imperial Orthodox Palestine Society]. T. 1-2, SPb., tipografiya V.F. Kirshbauma, 1907. 
7. Sistematicheskiy katalog biblioteki Imperatorskogo Palestinskogo Pravoslavnogo obschestva [Systematic catalog of the library of the Imperial Orthodox Palestine Society]. Dopolnenie k t. 1-2. SPb, 1913.

8. PismoV.D. Bonch-Bruevicha M.I. Shahnovichu. Noyabr 1952. Lichnyiy arhiv prof. M.I. Shahnovicha [Letter from V.D. Bonch-Bruevich to M.I. Shahnovich. November 1952 Personal Archive prof. M. I. Shakhnovich].

9. Salmina M.A. Dnevnik arhimandrita Antonina (Kapustina) [Diary of Archimandrite Antonin (Kapustin)] // Trudyi otdela drevnerusskoy literaturyi. T.27. Leningrad, 1972. S. 420-430.

10. Lisovoy N.N., Butova R.B. Arhimandrit Antonin i ego dnevnik [Archimandrite Antonin and his diary] // Dnevnik. God 1881. M., Indrik. 2011.

УДК 930.85

Коллекции Императорского Православного Палестинского общества в государственном музее истории религии (Санкт-Петербург, Россия)

\author{
1 Татьяна Витаутасовна Чумакова \\ 2 Марианна Михайловна Шахнович \\ 3 Екатерина Александровна Терюкова
}

1-3 Санкт-Петербургский государственный университет, Российская Федерация

199034 Санкт-Петербург, Менделеевская линия, дом 5

1 Доктор философских наук, профессор

E-mail: t.chumakova@spbu.ru

2 Доктор философских наук, профессор

E-mail:m.shakhnovich@spbu.ru

3 Кандидат философских наук, доцент

E-mail: e.teryukova@spbu.ru

Аннотация. Статья посвящена еще малоисследованной проблеме исследования коллекция Императорского Православного Палестинского Общества, которое было создано в России в 1882 году. Общество активно занималось не только организацией паломничеств в Святую Землю, но и организацией археологических и научных экспедиций на Ближний Восток. Важнейшим аспектом этой деятельности стало создание двух уникальных коллекций: библиотечной коллекции и фотоархива. Это исследование основано на материалах коллекций Императорского Православного Палестинского Общества, хранящихся в Государственном музее истории религии (Санкт-Петербург) и неопубликованных архивных материалах. Коллекции книг и фотодокументов, которые сохранились в коллекции Императорского Православного Палестинского общества отражают не только интеллектуальные запросы и предпочтения российских ученых, но история развития палестинской науки в России в конце XIX - в начале XX века в целом

Ключевые слова: Императорское Православное Палестинское общество, Русская культура, государственный музей истории религии, коллекции. 